Peran Ganda Wanita dan Kesejahteraan

\title{
PENGARUH PERAN GANDA WANITA DAN KESEJAHTERAAN KELUARGA TERHADAP PENDIDIKAN FORMAL
}

\author{
Hasti Santoso ${ }^{1}$
}

\begin{abstract}
Abstrak
Pendidikan memiliki peranan yang sangat penting untuk menghasilkan manusia yang berkualitas. Oleh sebab itu perlu adanya peningkatan kualitas pendidikan, salah satunya dengan melakukan penelitian-penelitian untuk kemajuan pendidikan. Penelitian ini tentang pendidikan formal anak di desa Sidorejo, kecamatan Jatisrono, Wonogiri. Penelitian ini bertujuan untuk mengetahui ada tidaknya pengaruh peran ganda wanita dan kesejahteraan keluarga terhadap pendidikan formal anak.

Penelitian ini menggunakan metode kuantitatif. Teknik pengambilan sampel yang digunakan adalah teknik sampling bertujuan "Purposive Sampling". Teknik ini digunakan kerena anggota sampel dipilih secara khusus berdasarkan tujuan penelitian. Populasi dalam penelitian ini adalah penduduk wanita desa Sidorejo, kecamatan Jatisrono, Kabupaten Wonogiri yang mempunyai peran ganda, yaitu sebagai ibu rumah tangga dan pekerja. Dari jumlah populasi sasaran di wilayah desa Sidorejo terdapat 420 orang wanita yang memiliki peran ganda, maka jumlah sampel setelah dihitung adalah 78 orang. Sumber data dalam penelitian ini adalah sumber data primer yang diperoleh melalui teknik angket dan sumber data sekunder melalui dokumentasi, wawancara dan observasi. Pengukuran validitas instrumen menggunakan teknik korelasi product moment. Teknik analisa data menggunakan uji normalitas, uji linearitas, uji multikolinearitas, dan uji heterokedastisitas.

Penelitian ini menggunakan uji-t untuk mengetahui ada tidaknya pengaruh peran ganda wanita dan kesejahteraan keluarga terhadap pendidikan formal anak. Hasil perhitungan menunjukkan bahwa pada tingkat kepercayaan $95 \%$ atau $a=0,05$ dan derajat kebebasan 75, diperoleh hasil $t$ hitung 4,212 sedangkan $t$ tabel 1,665425. sehingga dari perhitungan tersebut menunjukkan bahwa t hitung $=4,212>1,665425$ dengan tingkat signifikansi 0,000 jauh lebih kecil dari 0,05. ini berarti H0 ditolak dan Ha diterima, sehingga disimpulkan bahwa peran ganda wanita mempunyai pengaruh secara signifikan terhadap pendidikan formal anak dan diperoleh hasil $t$ hitung 3,624 sedangkan $t$ tabel 1,665425 . sehingga dari perhitungan tersebut menunjukkan bahwa $\mathrm{t}$ hitung $=$ 3,624 > 1,665425 dengan tingkat signifikansi 0,001jauh lebih kecil dari 0,05. ini berarti H0 ditolak dan Ha diterima, sehingga disimpulkan bahwa
\end{abstract}

\footnotetext{
${ }^{1}$ Penulis adalah alumni Program Studi Pendidikan Sosiologi, FISE, Universitas Negeri Yogyakarta
} 
kesejahteraan keluarga mempunyai pengaruh secara signifikan terhadap pendidikan formal anak

Kata kunci: Pendidikan Formal anak, Peran ganda wanita, Kesejahteraan Keluarga.

\section{A. Pendahuluan}

Dalam kehidupan masyarakat dewasa ini yang sering dihadapkan dengan permasalahan ekonomi, orang tua harus berjuang dengan keras untuk mencukupi kebutuhan keluarganya. Salah satu cara untuk mencukupi kebutuhan tersebut yakni dengan adanya pergeseran peran wanita, yaitu selain menjadi ibu rumah tangga juga sebagai pencari nafkah dalam keluarga. Dalam hal ini wanita tidak hanya menjalani fungsi domestik saja tetapi juga fungsi publiknya. Awalnya wanita hanya bekerja didalam rumah tangga saja, misalnya: mengasuh anak dan mempersiapkan kebutuhan rumah tangga. Kini wanita mampu bekerja di luar rumah, misal berdagang, bertani, wiraswasta bahkan menjadi pegawai negeri.

Pada masa sekarang ini telah terjadi perubahan/transformasi dari kegiatan ekonomi, dari bidang pertanian ke bidang perdagangan. Sehingga tugas pokok wanita dalam fungsi domestiknya bisa ditumbuhkembangkan dengan kegiatan-kegiatan di sektor yang lain, misalnya: katering yang menyediakan makanan, bekerja sebagai karyawan di sektor industri, berwirausaha, dan lain-lain. Dengan demikian wanita mempunyai peran ganda. Ada beberapa alasan yang mendorong wanita untuk bekerja, antara lain memenuhi kebutuhan ekonomi keluarganya, untuk mengatasi kejenuhan serta kesepian di rumah sehingga mereka bekerja, selain itu ada juga wanita yang bekerja untuk mengejar status.

Hasbullah, mengemukakan dasar-dasar tanggung jawab orang tua terhadap pendidikan anaknya yaitu sebagai berikut:

1. Adanya motivasi atau dorongan cinta kasih yang menjiwai hubungan orangtua dengan anaknya.

2. Pemberian motivasi kewajiban moral sebagai konsekuensi kedudukan orang tua terhadap keturunanya.

3. Tanggung jawab sosial adalah bagian dari keluarga yang pada gilirannya akan menjadi tanggung jawab masyarakat, Bangsa dan Negara.

4. Memelihara dan membesarkan anaknya.

5. Memberikan pendidikan dan ilmu pengetahuan dan keterampilan yang berguna bagi kehidupan anak kelak, sehingga bila ia telah dewasa akan mampu mandiri ${ }^{2}$

Dari hal yang telah dikemukakan di atas dapat kita lihat bahwa tanggung jawab orang tua selain memelihara dan membesarkan anaknya juga

\footnotetext{
${ }^{2}$ Hasbullah. Dasar-dasar Ilmu Pendidikan, PT Raja Grafindo Persada, Jakarta, 2005.hlm 44
} 
memberikan pendidikan dan ilmu pengetahuan kepada anaknya, sehingga berguna bagi kehidupan anaknya kelak. Dari hal yang telah dikemukaan di atas dapat dilihat pula bahwa motivasi orang tua (seorang ibu yang mempuyai peran ganda) antara lain dorongan cinta kasih sayang terhadap anaknya. Rasa sayang dan cinta kasih orang tua menyebabkan orang tua melakukan apa saja yang terbaik untuk anaknya, termasuk pemenuhan kebutuhan pendidikan anak.

Kesejahteraan keluarga juga berpengaruh pada pendidikan formal anak. Pandangan awam, sebuah keluarga dikatakan sejahtera jika telah terpenuhi kebutuhan ekonominya. Pada kenyataannya bukan itu saja, sebuah keluarga dikatakan sejahtera ketika telah mencukupi kebutuhan sosial psikologisnya seperti kebutuhan sandang, pangan, tempat tinggal, pendidikan, perawatan kesehatan, bahkan juga menyangkut tentang interaksi dengan keluarga, interaksi dengan lingkungan tempat tinggal dan transportasi .

Realitas di desa Sidorejo menunjukkan bahwa kesejahteraan keluarga di sana sebagian besar termasuk keluarga sejahtera III. Hasil observasi menunjukkan bahwa dari 967 Kepala Keluarga terdapat 285 keluarga prasejahtera, 229 keluarga sejahtera I, 122 keluarga sejahtera II, 331 keluarga sejahtera III, dan 1 keluarga sejahtera III plus. ${ }^{3}$

Meskipun sudah dapat dikatakan sebagai keluarga sejahtera tahap III yang sudah dapat memenuhi kebutuhan sosial psikologisnya termasuk pendidikan akan tetapi jenjang pendidikan yang dapat ditempuh dirasa masih kurang, karena sebagian besar penduduknya hanya sampai jenjang pendidikan SLTP dan SLTA, sedangkan masyarakat yang dapat menempuh pendidikan di perguruan tinggi masih sangat sedikit sekali. Dari keseluruhan jumlah penduduk hanya terdapat 33 orang yang telah mencapai pendidikan hingga ke perguruan tinggi.

Berdasarkan uraian di atas, maka rumusan masalah dalam penelitian ini adalah: "Apakah peran ganda wanita dan kesejahteraan keluarga mempunyai pengaruh terhadap pendidikan formal anak?".

\section{B. Tinjauan Pustaka}

1. Peran Ganda Wanita

Seseorang yang memiliki berbagai peran dalam kehidupannya biasanya disebut mempunyai peran ganda. Ishomuddin menjelaskan pengertian peran ganda yaitu:

"Seseorang yang mempunyai berbagai status sekaligus dan akibatnya berbagai peran dipikulnya. Misalnya seorang ulama dapat merangkap status sebagai

\footnotetext{
${ }^{3}$ Data Primer dari Kantor Desa Sidorejo Tahun 2009
} 
suami, pengusaha, ketua organisasi. Sebagai ulama ia melayani umat berkenaan dengan agama, sebagai suami ia mempunyai relasi khusus dengan istri dan anak-anaknya, sebagai pengusaha ia berhubungan dengan para pelanggan dalam dunia bisnis, sebagai ketua organisasi ia berhubungan dengan anggotanya." 4

Dari pendapat di atas dapat diartikan bahwa setiap manusia mempunyai berbagai peran dalam hidupnya, dan semua peran tersebut tergantung dari individu yang akan menjalankan peran tersebut. Begitu juga sebagai wanita, dapat berperan sebagai ibu rumah tangga tetapi juga dapat berperan sebagai pencari nafkah untuk membantu suaminya dalam pemenuhan kebutuhan ekonominya dengan bekerja. Dalam hal ini yang dimaksud dengan wanita yang bekerja adalah ibu/istri yang bekerja/melaksanakan kegiatan dengan tujuan untuk memperoleh penghasilan (pegawai negeri, swasta, dan wirausaha).

Meskipun dalam masyarakat tradisional wanita yang bekerja masih merupakan hal yang janggal tapi seiring dengan perkembangan zaman hal ini bisa diterima. Peran wanita bukan hanya sekedar sebagai ibu rumah tangga, akan tetapi bisa juga berperan sebagai pencari nafkah seperti suaminya, karena dalam agama Islam pun membenarkannya. "Islam sama sekali tidak menempatkan

\footnotetext{
Ishomuddin, Sosiologi Perspektif Islam. Universitas Muhammadiyah Malang. 2005. hlm 204.
}

perempuan pada posisi yang lebih rendah dibanding dengan laki-laki, baik dari segi penciptaannya, tugas dan fungsinya, hak dan kewajibannya, maupun dalam rangka meraih prestasi puncak yang diidam-idamkannya". ${ }^{5}$

Pada masa sekarang ini wanita tidak hanya berkecimpung dalam urusan rumah tangga saja tetapi telah ikut pula dalam bekerja mencari nafkah. Jumlah wanita yang bekerja dari tahun ke tahun selalu mengalami peningkatan. Wanita ikut bekerja yang dapat menambah pendapatan keluarga, secara langsung mempunyai peran ganda yaitu sebagai ibu rumah tangga dan sekaligus ikut mencari penghasilan bagi keluarganya.

\section{Kesejahteraan Keluarga}

Kesejahteraan yaitu: "kondisi terpenuhinya segala bentuk kebutuhan hidup yang bersifat mendasar seperti makanan, pakaian, perumahan, pendidikan, dan perawatan kesehatan". 6 Dari pengertian tersebut, konsep keluarga sejahtera dalam konteks penelitian ini antara lain mengandung pengertian: Keluarga yang segala kebutuhan hidupnya terpenuhi baik berupa makanan, tempat tinggal, perumahan pendidikan dan kesehatan.

Setiap keluarga berusaha untuk memenuhi kebutuhankebutuhannya, misalnya kebutuhan

\footnotetext{
5 Suryono dkk, Din Al-Islam Buku teks Pendidikan Agama Islam Di Perguruan Tinggi, UNY, 2002, Hlm 136.

6 Model-model Kesejahteraan Sosial Islam Perspektif Normatif Filosofis dan Praktis, Fakultas dakwah UIN, Yogyakarta. 2007
} 
dasar, kebutuhan sosialpsikologis, kebutuhan kebutuhan perkembangannya, dan lain-lain. Dalam kenyataannya keluarga yang satu dan keluarga yang lain memiliki kemampuan yang berbeda-beda dalam memenuhi kebutuhannya. Berdasar hal tersebut keluarga dibedakan menjadi beberapa tingkatan yaitu: (1) Keluarga pra sejahtera yaitu keluarga-keluarga yang belum dapat memenuhi kebutuhan dasarnya (basic needs) secara minimal, seperti kebutuhan akan pengajaran agama, pangan, sandang, papan, dan kesehatan, 2) Keluarga sejahtera tahap I yaitu keluarga-keluarga yang dapat memenuhi kebutuhan dasarnya secara minimal, tetapi belum dapat memenuhi secara keseluruhan kebutuhan sosial psikologisnya (socio psikologis needs). Seperti kebutuhan akan pendidikan, keluarga berencana, interaksi dalam kelurga, interaksi dengan lingkungan tempat tinggal dan transportasi, (3) Keluarga sejahtera tahap II yaitu keluarga-keluarga yang disamping telah dapat memenuhi kebutuhan dasarnya, juga telah dapat memenuhi seluruh kebutuhan sosial psikologisnya, akan tetapi belum dapat memenuhi seluruh kebutuhan perkembangannya (developmental needs) seperti kebutuhan untuk menabung dan memperoleh informasi, (4) Keluarga sejahtera tahap III yaitu keluarga-keluarga yang telah dapat memenuhi kebutuhan dasar, kebutuhan sosial psikologisnya dan kebutuhan pengembangannya, namun belum dapat memberikan sumbangan (kontribusi) yang maksimal terhadap masyarakat. Seperti secara teratur(waktu tertentu) memberikan sumbangan dalam bentuk materiil dan keuangan untuk kepentingan sosial kemasyarakatan serta berperan serta secara aktif dengan menjadi pengurus lembaga kemasyarakatan atau yayasan sosial, keagamaan, kesenian, olahraga, pendidikan dan sebagainya, (5) Keluarga sejahtera tahap III Plus yaitu keluargakeluarga yang telah dapat memenuhi seluruh kebutuhannya, baik yang bersifat dasar, sosial psikologis maupun yang bersifat pengembangan serta telah dapat pula memberikan sumbangan yang nyata dan berkelanjutan bagi masyarakat, dan aktif menjadi pengurus lembaga kemasyarakatan. ${ }^{7}$

\section{Pendidikan Formal Anak}

Pendidikan, seperti yang telah diungkapkan Hasbullah, yaitu sebagai berikut: "Dalam arti sederhana pendidikan sering diartikan sebagai usaha untuk membina kepribadiannya sesuai dengan nilai-nilai yang ada di dalam masyarakat dan kebudayaanya".8 Dalam GBHN menyebutkan bahwa pendidikan pada hakekatnya merupakan suatu

\footnotetext{
${ }^{7}$ Supriyadi, Dkk, Sewindu Pendataan Keluarga Propinsi Istimewa Yogyakarta. BKKBN DIY: Yogyakarta, 2002, Hlm 14.

${ }^{8}$ Hasbullah., Opcit. Hlm 1
} 
usaha sadar untuk mengembangkan kepribadian dan kesempurnaan baik di dalam maupun di luar lingkungan sekolah serta berlangsung seumur hidup. Lebih lanjut dijelaskan bahwa bentukbentuk pendidikan adalah sebagai berikut:

a. Pendidikan Formal

Pendidikan sekolah yang teratur, bertingkat dan mengikuti aturan-aturan yang ketat dan jelas terdiri dari: TK, SD, SLTP, SLTA, Akademi dan perguruan Tinggi.

b. Pendidikan Informal

Pendidikan yang diperoleh seseorang dari pengalaman seharihari dengan sadar ataupun tidak sadar dari seseorang lahir atau baik dalam lingkungan keluarga, bekerja maupun masyarakat.

c. Pendidikan Nonformal

Pendidikan yang teratur dengan sadar dilakukan tetapi tidak terlalu mengikuti peraturan yang ketat dan tetap, seperti kursus menjahit, mengetik, bahasa, komputer.

Dari ketiga bentuk pendidikan tersebut, pendidikan formallah yang paling penting. Ini bukan berarti pendidikan yang lain

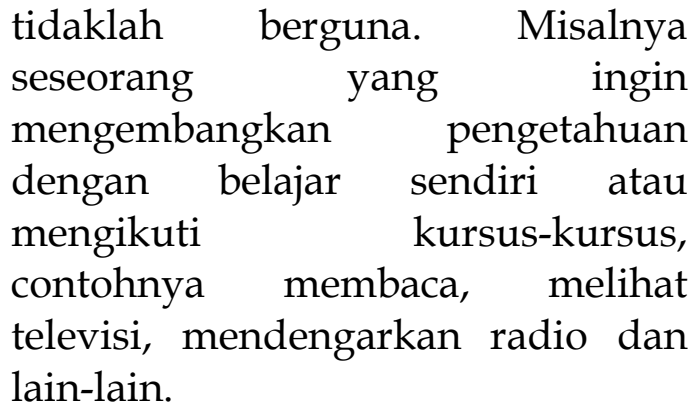

\section{Hipotesis Penelitian}

Berdasarkan dari landasan teori dan kerangka pemikiran di atas, maka penyusun mengajukan Hipotesa sebagai jawaban sementara sebagai berikut:

a. Ada pengaruh signifikan antara peran ganda wanita dan kesejahteraan keluarga terhadap pendidikan formal anak.

b. Ada pengaruh signifikan antara peran ganda wanita terhadap pendidikan formal anak.

c. Ada pengaruh signifikan antara kesejahteraan keluarga terhadap pendidikan formal anak.

Hubungan antara variabel tersebut dapat digambarkan sebagai berikut: 
Gambar 1

Hubungan Antara Variabel

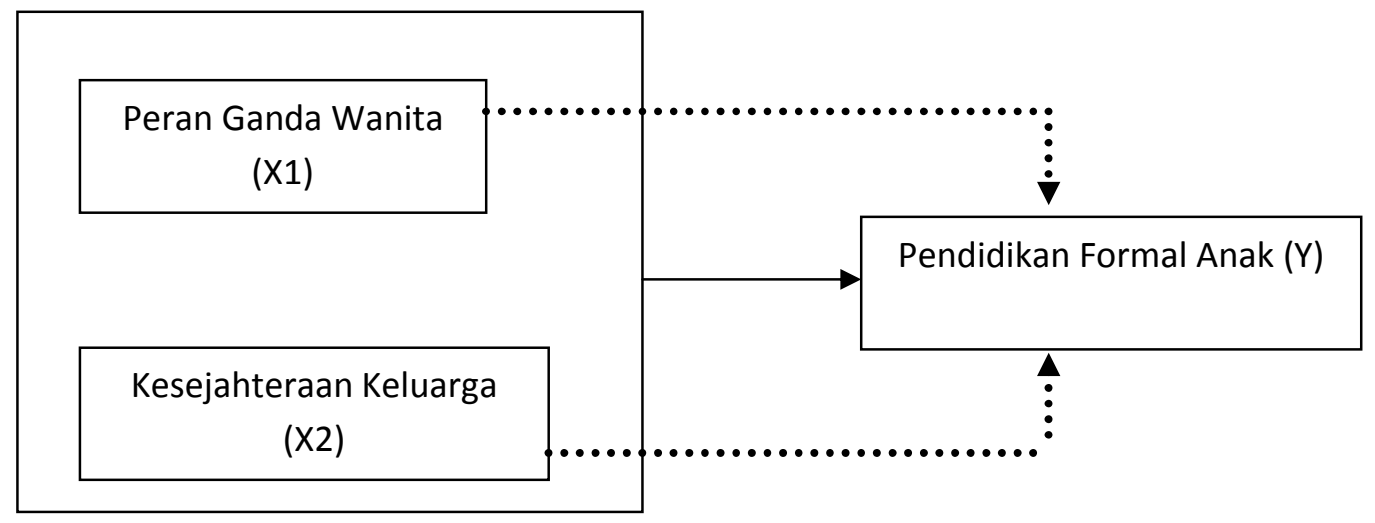

Keterangan:

X1 = Peran ganda Wanita sebagai Variabel Bebas 1

$\mathrm{X} 2$ = Kesejahteraan Keluarga sebagai Variabel Bebas 2

$\mathrm{Y}=$ Pendidikan formal anak sebagai Variabel Terikat

\section{Metode Penelitian}

Metode penelitian yang digunakan dalam penelitian ini menggunakan pendekatan kuantitatif karena penelitian ini bertujuan untuk mendeskripsikan, mencatat dan menginterpretasikan kondisi yang terjadi, karena hasil pengamatan berupa angka maka akan dianalisis dengan teknik statistik. Penelitian ini juga dikategorikan sebagai penelitian korelasional kerena peneliti mencoba menjelaskan hubungan antara variabel satu dengan variabel yang lain.

Definisi operasional variabel penelitian adalah sebagai berikut:

1. Peran ganda wanita dapat diungkapkan bahwa wanita memikul tugas sebagai ibu rumah tangga dan bekerja.

2. Kesejahteraan keluarga merupakan kondisi terpenuhinya segala bentuk kebutuhan hidup yang bersifat mendasar seperti makanan, pakaian, perumahan, pendidikan dan perawatan kesehatan

3. Pendidikan formal anak adalah pendidikan sekolah yang teratur bertingkat dan mengikuti aturan-aturan yang ketat dan jelas, terdiri dari: TK, SD, SLTP, SLTA, Akademi dan perguruan tinggi

Dari data penduduk, Desa Sidorejo terdapat 3463 jiwa dengan jumlah pria sebesar 1791 dan wanita 1672. Dari 967 kepala keluarga (KK) terdapat 420 wanita yang ikut bekerja mencari nafkah. Inilah yang penyusun pergunakan sebagai populasi. Besarnya jumlah sampel dalam penelitian ini menggunakan rumus yang dikemukakan Frank 
Lynch, dengan rumus sebagai berikut:

$$
n=\frac{N Z^{2} \cdot p(1-p)}{N d^{2}+\left[Z^{2} \cdot p(1-p)\right]}
$$

Keterangan:

$\mathrm{n}=$ Jumlah sampel

$\mathrm{N}=$ Jumlah populasi

$Z=$ Nilai normal dari variabel $(1,96)$

untuk tingkat kepercayaan $95 \%$

$\mathrm{P}=$ Harga patokan tertinggi $(0,50)$

$\mathrm{d}=$ Sampling Error $(0,10)$

Penentuan sampel dalam penelitian ini menggunakan teknik sampling bertujuan "Purposive Sampling". Teknik ini digunakan karena anggota sampel dipilih secara khusus berdasarkan tujuan penelitian. ${ }^{9}$ Lebih jauh Sutrisno Hadi menjelaskan: "Dalam purposive sampling pemilihan sekelompok subyek didasarkan atas ciri-ciri atau sifat-sifat tertentu yang dipandang mempunyai sangkut paut yang erat dengan ciri-ciri atau sifat-sifat populasi yang sudah diketahui sebelumnya. Nama purposive sampling menunjukkan bahwa teknik ini digunakan untuk memcapai tujuan-tujuan tertentu"10

Dalam hal ini yang dimaksud atau dibutuhkan dalam sampel penelitian adalah wanita atau istri yang mempunyai peran sebagai ibu rumah tangga dan juga berperan sebagai pencari nafkah dengan bekerja.

Instrumen yang digunakan dalam penelitian ini adalah dengan menggunakan angket. Angket ini

\footnotetext{
${ }^{9}$ Sutrisno Hadi, Metode Research I, Fakultas Psikologi UGM, 1982, Hlm 3

${ }^{10}$ Sutrisno Hadi. Statistik 2. Andi Offset. Yogyakarta. 1982. Hlm 226.
}

berisikan daftar pertanyaan yang ditujukan kepada responden untuk memperoleh data. Peneliti membuat daftar pertanyaan sendiri untuk memperoleh data mengenai peran ganda wanita, kesejahteraan keluarga dan pendidikan formal anak. Angket sebelumnya diuji cobakan kepada responden di luar sampel peneliti. Dari hasil uji coba, kemudian dilakukan uji validitas, sehingga alat ukur tersebut valid dan reliabel.

Adapun langkah-langkah yang ditempuh oleh peneliti dalam membuat instrument adalah terlebih dahulu mendefinisikan secara operasional konsep dari variabel yang didasarkan atas teori yang disusun sebelumnya. Instrumen yang digunakan dalam penelitian ini adalah untuk mengembangkan variabel beserta indikatornya yang meliputi tiga bagian yaitu peran ganda wanita, kesejahteraan keluarga dan pendidikan formal anak.

Uji validitas angket dilakukan dengan bantuan program SPSS 15,00 for Windows. Adapun korelasi yang digunakan adalah korelasi product moment dari Pearson. Uji validitas bertujuan untuk melihat apakah pertanyaanpertanyaan dalam kuesioner mampu mengukur apa yang hendak di ukur. Uji validitas dilakukan dengan menggunakan komputer program SPSS. Hasil perhitungan akan dibandingkan dengan kritik tabel korelasi nilai $\mathrm{r}$ dengan $\mathrm{df}=40$ taraf signifikansi $5 \%, r$ tabel $=$ 0.2018 , jika $r$ hitung lebih besar dari $r$ tabel, maka pertanyaan tersebut valid. Hasil perhitungan uji 
| Peran Ganda Wanita dan Kesejahteraan

validitas ditunjukkan dalam tabel sebagai berikut:

Tabel. 1

Validitas butir soal

\begin{tabular}{|c|c|c|c|c|c|}
\hline Variabel & $\begin{array}{c}\text { No } \\
\text { Item }\end{array}$ & r hitung & & $r$ tabel & Status \\
\hline \multirow{15}{*}{$\begin{array}{c}\text { Peran Ganda } \\
\text { Wanita }\end{array}$} & 1. & 0,3228 & $>$ & 0,2018 & Valid \\
\hline & 2. & 0,5554 & $>$ & 0,2018 & Valid \\
\hline & 3. & 0,3884 & $>$ & 0,2018 & Valid \\
\hline & 4. & 0,3903 & $>$ & 0,2018 & Valid \\
\hline & 5. & 0,1725 & $<$ & 0,2018 & Gugur \\
\hline & 6. & 0,4704 & $>$ & 0,2018 & Valid \\
\hline & 7. & 0,4835 & $>$ & 0,2018 & Valid \\
\hline & 8. & 0,2709 & $>$ & 0,2018 & Valid \\
\hline & 9. & 0,1231 & $<$ & 0,2018 & Gugur \\
\hline & 10. & 0,2311 & $>$ & 0,2018 & Valid \\
\hline & 11. & 0,4475 & $>$ & 0,2018 & Valid \\
\hline & 12. & 0,7339 & $>$ & 0,2018 & Valid \\
\hline & 13. & 0,3701 & $>$ & 0,2018 & Valid \\
\hline & 14. & 0,2271 & $>$ & 0,2018 & Valid \\
\hline & 15. & 0,3417 & $>$ & 0,2018 & Valid \\
\hline \multirow[t]{15}{*}{ Kesejahteraan } & 16. & 0,5656 & $>$ & 0,2018 & Valid \\
\hline & 17. & 0,2313 & $>$ & 0,2018 & Valid \\
\hline & 18. & 0,6811 & $>$ & 0,2018 & Valid \\
\hline & 19. & 0,3989 & $>$ & 0,2018 & Valid \\
\hline & 20. & 0,7333 & $>$ & 0,2018 & Valid \\
\hline & 21. & 0,7910 & $>$ & 0,2018 & Valid \\
\hline & 22. & 0,4331 & $>$ & 0,2018 & Valid \\
\hline & 23. & 0,6159 & $>$ & 0,2018 & Valid \\
\hline & 24. & 0,7351 & $>$ & 0,2018 & Valid \\
\hline & 25. & 0,7322 & $>$ & 0,2018 & Valid \\
\hline & 26. & 0,5357 & $>$ & 0,2018 & Valid \\
\hline & 27. & 0,6979 & $>$ & 0,2018 & Valid \\
\hline & 28. & 0,5816 & $>$ & 0,2018 & Valid \\
\hline & 29. & 0,6815 & $>$ & 0,2018 & Valid \\
\hline & 30 & 0,1986 & $<$ & 0,2018 & Gugur \\
\hline \multirow{5}{*}{$\begin{array}{l}\text { Pendidikan } \\
\text { Formal Anak }\end{array}$} & 31. & 0,295 & $>$ & 0,2018 & Valid \\
\hline & 32. & 0,5917 & $>$ & 0,2018 & Valid \\
\hline & 33. & 0,705 & $>$ & 0,2018 & Valid \\
\hline & 34. & 0,7193 & $>$ & 0,2018 & Valid \\
\hline & 35. & 0,6695 & $>$ & 0,2018 & Valid \\
\hline
\end{tabular}

DIMENSIA, Volume 3, No. 2, September 2009 | 77 


\begin{tabular}{|c|c|c|c|c|c|}
\hline & 36. & $-0,096$ & $<$ & 0,2018 & Gugur \\
\cline { 2 - 6 } & 37. & 0,4182 & $>$ & 0,2018 & Valid \\
\cline { 2 - 6 } & 38. & 0,705 & $>$ & 0,2018 & Valid \\
\cline { 2 - 6 } & 39. & 0,5997 & $>$ & 0,2018 & Valid \\
\cline { 2 - 6 } & 40. & $-0,013$ & $<$ & 0,2018 & Gugur \\
\hline
\end{tabular}

Sumber: Hasil Pengolahan dengan SPSS 15

Dari hasil pengujian validitas pada tabel di atas, dapat diketahui bahwa item gugur variabel peran ganda adalah no 5 dan 9, variabel Kesejahteraan item no 30 dan variabel pendidikan formal item no 36 dan 40. Untuk item yang dinyatakan gugur tidak akan diikutkan dalam analisis selanjutnya.

Untuk menguji reliabilities angket menggunakan analisis factor dengan menggunakan program SPSS 15,00 for Windows. Uji reliabilitas dilakukan dengan menghitung koefisien reliabilitas setiap factor langkah selanjutnya dengan menghitung koefisien reliabilitas gabungan dari seluruh factor pada setiap variabel. Hasil perhitungan Reliabilitas sebagai berikut:

Tabel 2

Hasil Uji Reliabilitas

$\begin{array}{llll}\text { Variabel } & \text { ralpha } & \text { rtabel } & \text { status } \\ \text { Peran Ganda } & 0,781 & 0,2018 & \text { Reliabel } \\ \text { Kesejahteraan } & 0,899 & 0,2018 & \text { Reliabel } \\ \text { Pendidikan Formal } & 0,854 & 0,2018 & \text { Reliabel }\end{array}$

Dari hasil pengujian reliabilitas seperti pada tabel diatas dapat disimpulkan bahwa semua faktor reliabel. Berdasarkan analisis diperoleh koefisien alpha untuk variabel peran ganda wanita sebesar $(0,781)$ termasuk dalam kategori (tinggi). Koefisien alpha variabel kesejahteraan keluarga sebesar $(0,899)$ termasuk dalam kategori (sangat tinggi) dan koefisien Alpha Variabel Pendidikan Formal anak sebesar $(0,854)$ termasuk dalam kategori (sangat tinggi).
D. Pembahasan

\section{Analisis Regresi Linier Berganda}

Analisis regresi bertujuan untuk mengetahui hubungan variabel independen yaitu perna ganda wanita dan kesejahteraan terhdap variabel dependen yaitu pendidikan formal anak. Dari hasil pengolahan data diperoleh model regresi linier berganda sebagai berikut:

$\mathrm{Y}=\mathrm{a}+\mathrm{b} 1 \mathrm{X} 1+\mathrm{b} 2 \mathrm{X} 2$

$Y=-0,382+0,552 X 1+0,479 X 2$

Di mana:

$\mathrm{a}=-0,382$ artinya apabila peran ganda wanita dan kesejahteraan 
tetap atau tidak mengalami penambahan atau pengurangan maka nilai pendidikan formal memburuk (negatif) yaitu $-0,382$

$\mathrm{b} 1=0,552$, artinya satuan nilai peningkatan variabel pendidikan formal anak, apabila ada penambahan satuan pada variabel peran ganda wanita dimana variabel kesejahteraan tidak mengalami penambahan

b2 = 0,479, artinya satuan nilai peningkatan variabel pendidikan formal anak, apabila ada penambahan satuan pada variabel kesejahteraan dimana variabel peran ganda tidak mengalami penambahan

\section{Uji Koefisien Determinasi Berganda ( $\left.\mathbf{R}^{2}\right)$}

Dari Hasil perhitungan dengan bantuan komputer menunjukkan koefisien determinasi berganda yang telah disesuaikan (adjusted $\mathrm{R}$ square) yaitu sebesar 0,563 (maksud disesuaikan untuk derajat kebebasan (df) yang berkaitan dengan jumlah kuadrat yang ada). Hal ini berarti 56,3\% variasi pendidikan formal anak bisa dijelaskan oleh kedua variabel, sedangkan sisanya dijelaskan sebabsebab yang lain.

\section{Pengujian Signifikansi Koefisien Regresi dengan Uji F}

Pengujian ini dimaksudkan untuk mengetahui apakah kedua variabel bebas secara bersama-sama mempunyai hubungan signifikan dengan pendidikan formal anak. Pengujian ini akan dilakukan dengan menggunakan uji $\mathrm{F}$, pada tingkat kepercayaan 95\% ( $\alpha=0,05)$ dan derajat kebebasan (k-1, n-k) yaitu $(2,75)$. Dari uji ANOVA atau $\mathrm{F}$ test, didapat $\mathrm{F}$ hitung adalah 48,390 dengan tingkat signifikansi 0,000 dan $F$ tabel 3,118642. jadi $F$ hitung $48,390>\mathrm{F}$ tabel 3,118642 dengan probabilitas $(0,0000)$ jauh lebih kecil dari 0,05. maka hipotesis nol ditolak dan hipotesis alternatif diterima. Hal ini berarti variabel peran ganda wanita dan kesejahteraan secara bersama-sama mempunyai pengaruh yang signifikan terhadap pendidikan formal anak.

\section{Pengujian Signifikansi Koefisien Regresi dengan Uji t}

Uji $t$ digunakan untuk mengetahui hubungan masingmasing variabel bebas (peran ganda wanita dan kesejahteraan) terhadap variabel dependen (pendidikan formal anak). Dari hasil pengujian ini, apabila hasil $t$ hitung $>t$ tabel atau -t hitung $<-\mathrm{t}$ tabel pada tingkat kepercayaan $95 \%$ atau $\alpha=0,05$ dan derajat kebebasan (n-k) adalah 75, maka hipotesis nol ditolak dan hipotesis alternatif diterima, yang berarti ada hubungan yang signifikan. Apabila hasil $-\mathrm{t}$ tabel $<\mathrm{t}$ hitung, $\mathrm{t}$ tabel pada tingkat kepercayaan dan derajat kebebasan yang sama, maka hipotesis nol diterima dan hipotesis alternatif ditolak, yang berarti tidak ada hubungan.

a. Pengujian signifikansi antara variabel peran ganda wanita 
dengan pendidikan formal anak

Hipotesis yang diuji

$\mathrm{H} 0: ß 1=0$

Ha : $ß 1 \neq 0$

Dari hipotesis tersebut, pada tingkat kepercayaan 95\% atau $a=$ 0,05 dan derajat kebebasan 75, diperoleh hasil $t$ hitung 4,212 sedangkan $t$ tabel 1,665425 . sehingga dari perhitungan tersebut menunjukkan bahwa $\mathrm{t}$ hitung $=$ $4,212>1,665425$ dengan tingkat signifikansi 0,000 jauh lebih kecil dari 0,05. ini berarti H0 ditolak dan Ha diterima, sehingga disimpulkan bahwa peran ganda wanita mempunyai pengaruh secara signifikan terhadap pendidikan formal anak

b. Pengujian signifikansi antara variabel kesejahteraan dengan pendidikan formal anak

Hipotesis yang diuji

$\mathrm{H} 0: ß 2=0$

Ha : $ß 2 \neq 0$

Dari hipotesis tersebut, pada tingkat kepercayaan 95\% atau $\alpha=$ 0,05 dan derajat kebebasan 75, diperoleh hasil $t$ hitung 4,212 sedangkan $t$ tabel 1,665425. sehingga dari perhitungan tersebut menunjukkan bahwa $\mathrm{t}$ hitung $=$ 3,624>1,665425 dengan tingkat signifikansi 0,001 jauh lebih kecil dari 0,05. ini berarti H0 ditolak dan Ha diterima, sehingga disimpulkan bahwa peran ganda wanita mempunyai pengaruh secara signifikan terhadap pendidikan formal anak.

\section{E. Kesimpulan}

Penelitian ini menggunakan 3 variabel, yaitu: variabel peran ganda wanita dan variabel kesejahteraan keluarga sebagai variabel bebas, dan variabel pendidikan formal anak sebagai variabel terikat. Berdasarkan hasil analisis yang telah dilakukan dapat disimpulkan sebagai berikut:

1. Variabel peran ganda wanita dan kesejahteran secara bersama-sama mempunyai pengaruh yang signifikan terhadap pendidikan formal anak. Dari uji ANOVA atau $F$ test, didapat $\mathrm{F}$ hitung adalah 48,390 dengan tingkat signifikan 0,000 , karena probabilitas $(0,000)$ jauh lebih kecil dari 0,05, maka hipotesis nol ditolak dan hipotesis alternatif diterima

2. Variabel peran ganda wanita mempunyai pengaruh yang signifikan dengan pendidikan formal anak. Dari perhitungan uji $\mathrm{t}$ diperoleh $\mathrm{t}$ hitung 4,212 > t tabel 1,665425 dengan tingkat signifikan 0,000

3. Variabel kesejahteraan mempunyai pengaruh yang signifikan dengan pendidikan formal anak. Dari perhitungan uji $\mathrm{t}$ diperoleh $\mathrm{t}$ hitung 3,624 $>\mathrm{t}$ tabel 1,665425 dengan tingkat signifikan 0,001

4. Dari Hasil perhitungan dengan bantuan komputer menunjukkan koefisien determinasi berganda yang telah disesuaikan (adjusted $\mathrm{R}$ square) yaitu sebesar 0,563 (maksud disesuaikan untuk derajat kebebasan (df) yang berkaitan dengan jumlah 
| Peran Ganda Wanita dan Kesejahteraan

kuadrat yang ada). Hal ini berarti 56,3 \% variasi pendidikan formal anak bisa dijelaskan oleh kedua variabel, sedangkan sisanya dijelaskan sebab-sebab yang lain.

\section{Daftar Pustaka}

Hasbullah. Dasar-dasar Ilmu Pendidikan, PT Raja Grafindo Persada, Jakarta, 2005.

Ishomuddin, Sosiologi Perspektif Islam. Universitas Muhammadiyah Malang. 2005.

Supriyadi, Dkk, Sewindu Pendataan Keluarga Propinsi Istimewa Yogyakarta. BKKBN DIY: Yogyakarta, 2002.

Suryono dkk, Din Al-Islam Buku teks Pendidikan Agama Islam Di Perguruan Tinggi, UNY, 2002.

Sutrisno Hadi, Metode Research I, Fakultas Psikologi UGM, 1982.

Sutrisno Hadi. Statistik 2. Andi Offset. Yogyakarta. 1982. 